\title{
Analysis and Research on Science Technology Students' English Learning Strategies and Motivation
}

\author{
Ling Zhang \\ Faculty of Humanities and Foreign Languages \\ Xi'an University of Technology \\ Xi'an, China 710054
}

\begin{abstract}
The author made a questionnaire survey on 95 students of science and technology. This article studies and analyzes their English learning strategies and motivation. The data shows that learning strategies and motivations are positively correlated with grades. Based on the results of the survey, the author put forward some suggestions for college English education for science technology students.
\end{abstract}

Keywords—science technology students; learning strategies; learning motivation

\section{INTRODUCTION}

With the progress of globalization, China urgently needs a large number of high-quality engineering and technical talents who have good innovative abilities and can meet the needs of economic and social development. This requires science and technology students to have higher English levels. They must not only possess solid professional knowledge, but also be able to use English proficiently to facilitate better engineering practice and academic exchange in the international arena. Because students of science and technology have special knowledge structure, thinking mode, cognitive characteristics and professional development direction compared with liberal arts students, they also have their own English learning characteristics and problems. Therefore, the author conducted a survey for some science technology students, studied and analyzed their English learning strategies and motivations, and made some suggestions on the English education for students of science and technology based on the findings.

\section{RESEARCH METHODS}

\section{A. The Purpose of the Survey}

The purpose of this study: 1.To analyze the English learning strategies of science and technology students; 2. To study the motivations of science and technology students to learn English; 3. To analyze the effects of learning strategies and motivation on learning results.

\section{B. The Survey Objects}

This study was conducted on 98 science and technology students of the second grade under Xi'an University of Technology. They are from majors of materials, vehicle engineering, mechanical design and automation, computer, measurement and control, applied chemistry, civil engineering, and pharmaceutical engineering. All interviewees have received at least 6 years of formal English education.

\section{Survey Tools}

There are two survey tools used in this study: the CET-4 grades of the respondents and a self-designed questionnaire about science and technology students' English learning strategies and motivation. The questionnaire is divided into two parts. The first part is about learning strategies (containing a total of 18 questions). The answer to each question is divided into five levels just as Likert scale, ie 5=Completely accord, 4=Basically accord, 3= Difficult to judge, $2=$ does not quite accord, $1=$ does not accord at all. The corresponding scores 1 , $2,3,4$, and 5 are respectively assigned to them (the second, 15 th, and 18th questions are rhetorical, and the corresponding conversions have been made when the data was processed), and the total score is 90; The second part is about the motivation of learning (containing a total of 16 questions). The answer to each question is also graded just as Likert scale, ie $5=$ strongly agree, 4=basically agree, 3=difficult to judge, $2=$ don't quite agree, $1=$ Disagree. The questionnaires should be completed and recycled in class. In order to ensure the credibility of the survey, before the questionnaires were issued, students had been told that (1) they should fill in the questionnaires according to the actual situation, (2) the survey wouldn't have any influence on their English scores (3) this survey was to help teachers know students' English learning conditions and better arrange future teaching. In this survey, 98 questionnaires were distributed and they were all retrieved, among which there are 3 invalid questionnaires (have not been included in the statistics).

\section{DATA COLLECTION AND ANALYSIS}

98 students were grouped according to their CET-4 scores and divided into high score group (group A), medium score group (group B) and low score group (group C). Students with scores of 510 or higher were assigned to group A, students with scores of 425 to 509 were assigned to group B, and students with scores of 425 or lower were assigned to group C.

\section{A. Analysis of Learning Strategies}

There are two major learning strategies included in this questionnaire: metacognitive strategy and language learning 
strategy. "Meta-cognition" was first proposed by the American psychologist J.H.Flavell (1977) in his book "Cognitive Development". He explained that "meta-cognition" referred to "a cognitive subject's knowledge of his cognitive processes, cognitive results, and related activities, including the cognition for cognitive processes which are currently occurring(dynamics), self-cognitive abilities (static) and the interaction between the two above, and including the positive monitoring and regulation of these processes" (Flavell, 1984: 1). Brown (1987) interpreted metacognition as "the cognitive subject's understanding of his own knowledge and his control over his cognitive system".

As can be seen from "Table I", there are significant differences in learning strategies between Group A, Group B, and Group C. The learning strategies of Group A are significantly better than those of Group C. Related research shows that metacognitive strategies can help students improve their academic performance. Especially after a period of study, metacognitive strategies will be obviously positively correlated with academic performance (Pokay, P. \& Blumenfeld P. C 1990) [1]. The survey also got the same conclusion.

TABLE I. AVERAGE SCORES OF THE USE OF LEARNING STRATEGIES OF GROUP A, B AND C

\begin{tabular}{|l|l|l|l|}
\hline & Group A & Group B & Group C \\
\hline $\begin{array}{l}\text { The average score of learning } \\
\text { strategies }\end{array}$ & 60.5 & 53.7 & 50.3 \\
\hline
\end{tabular}

From "Table II", it can be seen that in the use of the metacognitive strategies from the first to the sixth question, group $\mathrm{A}$ has the best performance and group $\mathrm{C}$ has the worst performance. Among these questions, group $\mathrm{A}$ and group $\mathrm{C}$ differ the most at question 1 and 6, indicating that group A can better conduct autonomous learning, while group $\mathrm{C}$ lacks the initiative to learn; group A can constantly reflect on their own learning strategies, evaluate and feed back their learning results and deficiencies in time, while group $\mathrm{C}$ lacks the consciousness to correct their learning strategies.

It can be found from the interview after the survey that most students believe that mastering good learning methods is very important for learning English. However, in real life, they usually can not master the right method to learn. From the second item in "Table II", we can see that most students still learn by rote in vocabulary learning. The inefficiency of this method directly reduces the enthusiasm of students to learn English. It can make students feel frustrated and affect their academic performances in the learning process.
TABLE II. USAGE OF LEARNING STRATEgIES OF GRoup A, B, AND C

\begin{tabular}{|c|c|c|c|c|}
\hline No. & Content & $\begin{array}{c}\text { The } \\
\text { Average } \\
\text { Score of } \\
\text { Group A } \\
\end{array}$ & $\begin{array}{c}\text { The } \\
\text { Average } \\
\text { Score of } \\
\text { Group B } \\
\end{array}$ & $\begin{array}{l}\text { The } \\
\text { Average } \\
\text { Score of } \\
\text { Group C } \\
\end{array}$ \\
\hline 1 & $\begin{array}{l}\text { I can learn } \\
\text { independently in my } \\
\text { time }\end{array}$ & 3.7 & 3.0 & 2.1 \\
\hline 2 & $\begin{array}{l}\text { In college, there is an increase } \\
\text { in vocabulary. I still use rote } \\
\text { learning. }\end{array}$ & 3.2 & 3.0 & 2.7 \\
\hline 3 & $\begin{array}{l}\text { I often reflect on my English } \\
\text { learning conditions and } \\
\text { improve my deficiencies }\end{array}$ & 3.3 & 3.0 & 2.9 \\
\hline 4 & $\begin{array}{l}\text { I can take the initiative to } \\
\text { review what I have learned } \\
\text { and sort out and summarize } \\
\text { them }\end{array}$ & 2.9 & 2.5 & 2.5 \\
\hline 5 & $\begin{array}{l}\text { I can arrange my study well } \\
\text { and make a learning plan }\end{array}$ & 3.5 & 3.2 & 3.1 \\
\hline 6 & $\begin{array}{l}\text { I can find my own English } \\
\text { learning method according to } \\
\text { my personality }\end{array}$ & 3.9 & 3.5 & 3.0 \\
\hline 7 & $\begin{array}{l}\text { In addition to the listening } \\
\text { materials provided by teachers } \\
\text { in class, I will find other } \\
\text { listening materials to practice }\end{array}$ & 3.7 & 3.1 & 2.9 \\
\hline 8 & $\begin{array}{l}\text { In listening class, I will take } \\
\text { notes while listening }\end{array}$ & 3.5 & 2.9 & 2.5 \\
\hline 9 & $\begin{array}{l}\text { When listening to materials, I } \\
\text { pay attention to both the } \\
\text { content and the language } \\
\text { forms }\end{array}$ & 4.7 & 2.9 & 2.9 \\
\hline 10 & $\begin{array}{l}\text { In class I will actively look for } \\
\text { opportunities to speak in } \\
\text { English }\end{array}$ & 2.7 & 2.5 & 2.1 \\
\hline 11 & $\begin{array}{l}\text { I will actively seek } \\
\text { opportunities to communicate } \\
\text { with others in English }\end{array}$ & 2.5 & 2.3 & 2.1 \\
\hline 12 & $\begin{array}{l}\text { When reading intensive } \\
\text { materials, I try to understand } \\
\text { every sentence and every } \\
\text { word, and understand the } \\
\text { content of the entire article. }\end{array}$ & 3.4 & 3.2 & 3.4 \\
\hline 13 & $\begin{array}{l}\text { When reading articles, I will } \\
\text { first browse through the ideas } \\
\text { and then read them carefully }\end{array}$ & 3.8 & 3.7 & 4.0 \\
\hline 14 & $\begin{array}{l}\text { When reading intensive } \\
\text { materials, I will first guess the } \\
\text { meaning of new words and } \\
\text { then go to the dictionary }\end{array}$ & 3.9 & 3.5 & 3.3 \\
\hline 15 & $\begin{array}{l}\text { When reading extracurricular } \\
\text { materials, I use the same } \\
\text { method as reading intensive } \\
\text { materials. }\end{array}$ & 2.9 & 3.0 & 3.4 \\
\hline 16 & $\begin{array}{l}\text { If I don't understand the } \\
\text { sentence, I will analyze the } \\
\text { grammar structure of it and } \\
\text { find the main clause and } \\
\text { subordinate clause. }\end{array}$ & 3.4 & 3.4 & 3.2 \\
\hline 17 & $\begin{array}{l}\text { In life, I will take notes, leave } \\
\text { messages, write letters or keep } \\
\text { diaries in English }\end{array}$ & 2.6 & 2.3 & 2.4 \\
\hline 18 & $\begin{array}{l}\text { When writing in English, I } \\
\text { will first organize sentences in } \\
\text { Chinese and then translate } \\
\text { them into English. }\end{array}$ & 3.3 & 2.9 & 3.1 \\
\hline
\end{tabular}


It can be seen from the items 7, 8, and 9 of "Table II" that the listening learning strategies of group A are significantly better than those of group B and group $C$. The strategies of group $\mathrm{B}$ and $\mathrm{C}$ are not significantly different. Most of the students only practice listening using the materials provided by the teacher. Few people will find other suitable materials to practice listening after class. From post-survey interviews, it is found that students with lower scores do not have the habit of taking notes in intensive listening classes. This is mainly because there are too many sentences they can't understand, so they don't know where to start and it is easy for them to be distracted during listening. The 9th item is worth noting, on this item group A (10.5\% of the total students), group B (51.6\% of the total students), and group C (37.9\% of the total students) differ a lot from each other, indicating that there are few students who pay attention to language forms when listening to the materials. Students mainly use their mother language to think. They can't positively use English to think. From the 10th and 11th items, it can be seen that Group A uses better speaking strategies than Group B and C. This shows that Group A is superior to Group B and Group C in language expressing ability and generalization ability, and students in group A know how to overcome anxiety when expressing in English. However, the overall score of English speaking is not high, indicating that the three groups $\mathrm{A}, \mathrm{B}$, and $\mathrm{C}$ seldom use English to communicate with others. From item 16, it can be seen that a considerable number of students rely on their mother tongue when reading English materials and cannot analyze the language forms and grammatical features of English. The 17th item reflects that science and technology students rarely use English to write. Item 10 and 11 reflect that students' language output ability is weak.

\section{B. Analysis of Learning Motivation}

According to the power source of motivation, learning motivation can be divided into intrinsic learning motivation and extrinsic learning motivation. Intrinsic motivation, also known as internal motivation, comes from the interior of the student. Intrinsic motivational factors such as students' interest in learning, desire for knowledge, desire to improve their abilities, etc., will motivate students to positively learn. Extrinsic motivation, also known as external motivation, refers to the individual's motivation caused by external incentives. Learning is only a means for these students to achieve their other goals. For example, some students study hard to obtain rewards from teachers or parents; some study to avoid being punished by teachers or parents. Their purpose is not to learn knowledge. It is to achieve other purposes.

From the first item in "Table III", it can be seen that there is a positive correlation between learning interest and learning achievement. The learning interest of Group A is significantly higher than that of Group C. Item 8 shows that Group A is more willing to regard learning English as a challenge from which they can obtain satisfaction and sense of accomplishment. Item 9 shows that group A's interest in European and American cultures is significantly greater than that of group B and C. Group A students hope to learn more about English and better interact with them by learning English. The above results all indicate that the intrinsic motivation of group A is stronger than that of the other two groups. The second item reflects that most students in group $\mathrm{C}$ learn English for the purpose of obtaining certificates, while the 16th item indicates that the learning motivation of group $\mathrm{C}$ is mainly caused by the extrinsic factors of satisfying others or pleasing others.

It is worth mentioning that we can see from the 12th and 13th items that the learning motivation of Group B students is largely inspired by English classes and teaching materials. That is to say, good classes and excellent teaching materials can motivate these students.

\section{INSPIRATION AND SUGGESTIONS FOR COLLEGE ENGLISH TEACHING}

\section{A. Carry out Learning Strategy Teaching to Improve Students' Independent Learning Ability and Learning Efficiency}

Learning strategies are extremely important to students. They can directly affect students' learning efficiency. The author found in the survey that the science and technology students' strategies for learning English were generally poor. Students who use good learning strategies usually have relatively high scores in CET-4. Educators believe that learning strategies are teachable and transferable. Therefore, in order to improve science technology students' English grades and English learning efficiency, teachers should teach students to use good learning strategies, carry out learning strategy teaching, help students develop good study habits and get rid of bad habits. English teachers are not just for imparting knowledge and skills, they are also supposed to train students in learning strategies. They should combine the teaching of English learning strategy with English teaching considering the characteristics of science and technology students, and guide students to use different learning strategies for different learning tasks.

\section{B. Focus on the Needs of Science Technology Students to Intensify Their English Learning Motivation}

Science technology students have relatively heavy learning burdens. English teachers should think about how to help students handle the relationship between English and other subjects. English teachers should make teaching plans in accordance with the characteristics of science and technology majors and the professional needs of these majors. For the problem that science and technology students are not active in answering questions and are afraid of giving wrong answers, teachers should set some questions with moderate difficulty, encourage students to answer, give them help and full understanding, and give them some rewards when needed, such as raising their usual grades and so on. When they have some extrinsic motivation, teachers can try to turn it into intrinsic motivation [2].

\section{CONCLUSION}

It plays non-negligible role in guiding students to establish a good learning strategy. Effective training on English learning strategy can help students improve their learning and reduce 
the learning burden. Learning motivation will stimulate the learner's learning behavior, guide the learning direction. The students can have successful foreign language learning experience. Learning strategies influence learning motivation, and learning motivation is also influenced by learning strategies. In college English teaching, teachers should consciously help students improve their learning strategies and stimulate their learning motivation. It can achieve better teaching results.

\section{REFERENCES}

[1] Pokay,P. \& Blumenfeld P.C,Predicting achievement early and late in the semester:The role of motivation and of learning strategies. Journal of educational psychology,1990,82(1).

[2] BROWN H D. Teaching by Principles: An Interactive Approach to Language Pedagogy[M]. Beijing: Foreign Language Teaching and Research Press,2001.

[3] Wen Qiufang, Wang Haixiao. An Analysis of College Students' English Learning Concepts and Strategies [J]. Journal of PLA University of Foreign Languages, 1996, (4),pp. 61-66.

[4] Liu Runqing, "On College English Teaching" [M], Beijing: Foreign Language Teaching and Research Press, 1999.

[5] Feng Mei, A Survey of Science Technology Students' Psychology in English Learning[J]. Foreign Language Teaching and Research. 1995(2) .

[6] (English) Cook, V.. Second Language Learning and Teaching [M]. Beijing: Foreign Language Teaching and Research Press, 2000. 